Brit. J. industr. Med., 1964, 21, 308.

\title{
KINETICS OF THE DISTRIBUTION AND EXCRETION OF LEAD IN THE RAT
}

\author{
BY \\ N. CASTELLINO and S. ALOJ \\ From the Institute of Industrial Medicine of the University, \\ and the Institute of General Pathology of the University, Naples
}

(RECEIVED FOR PUBLICATION NOVEMBER 11, 1963)

\begin{abstract}
The kinetics of the distribution and excretion of lead $\left({ }^{210} \mathrm{~Pb}\right)$ were studied in rats for 14 days after single intravenous injections of $100 \mu \mathrm{g}$. of lead per rat.

The results show that in the blood the lead is bound mainly to the cells, and that the ratio of lead in the cells and plasma is constant throughout the whole period. ${ }^{210} \mathrm{~Pb}$ is rapidly distributed in the tissues, the highest concentrations being in the kidneys, liver, and bones.

The kinetics of the disappearance of ${ }^{210} \mathrm{~Pb}$ from the organs and tissues follow the pattern of first order reactions. The disappearance curves in the blood, plasma, haematic cells, and some other tissues can be expressed as sums of exponential functions. In contrast, the removal of metal from the bone tissue occurs at a constant and extremely slow rate.

The metal is excreted by the faeces and urine. The rates reach their maxima within 24 hours and decrease asymptotically afterwards. More ${ }^{210} \mathrm{~Pb}$ was excreted in the faeces $(35.7 \%)$ than in the urine $(15.9 \%)$ during the 14 days of observation.
\end{abstract}

In lead poisoning the absorption and distribution of the metal and the mechanism and rates of its excretion are all open to discussion. Mortensen and Kellogg (1944), Schubert and White (1952), Calhoun, McLean, Hudson, and Aub (1954), and Miani and Viterbo (1958) studied its distribution in various mammalian species using radioactive lead(radiumD) and found that in blood lead is mainly bound to the cells and is also fixed in the liver, kidney, and bone. It is excreted in the faeces and urine. These authors do not provide much evidence about the rates of distribution and excretion.

Our knowledge of lead metabolism also is incomplete. The literature is conflicting on the chemical state of the metal in the blood and urine. Aub, Fairhall, Minot, and Reznikoff (1925) isolated lead in the blood as colloidal di-lead phosphate, whereas Maxwell and Bischoff (1929) isolated it as the diphosphoglycerate. According to Jowett (1932), lead in the blood forms inorganic mixed salts with calcium and chloride, whereas Teisinger (1935) found that lead formed an organic complex. At present it is believed that lead is bound mainly to the erythrocytes (Mortensen and Kellogg, 1944; Schubert and White, 1952; and Teisinger, Zumanová, and Zezula, 1958), but the nature of the binding is un- known. In the urine also the lead is excreted in various forms. Nelson and Hamm (1958) consider that it is ' bound as a strong neutral or negatively charged chelate or complex', while according to Dinischiotu, Nestorescu, Radulescu, Ionescu, Preda, and Ilutza (1960) in the urine of normal subjects it is excreted in a precipitable form, but in subjects exposed to lead-with or without signs of intoxication-it is excreted in both precipitable and non-precipitable forms. The precipitable form is ionic, probably as lead phosphate, whereas the non-precipitable form is in some organic combination.

The fact that lead is found in different states of combination shows that its metabolism is complex, and it is reasonable to expect that this will be reflected in complex kinetics of distribution and excretion. Our aim has been to determine the rates of these processes in order to throw some light on metabolism.

\section{Methods}

Animals.-Wistar male rats weighing $190 \mathrm{~g}$. (180 to $225 \mathrm{~g}$.) were used.

Tracer Compound.- ${ }^{210} \mathrm{~Pb}$ acetate was supplied by the Radio-chemical Centre, Amersham, with a specific 


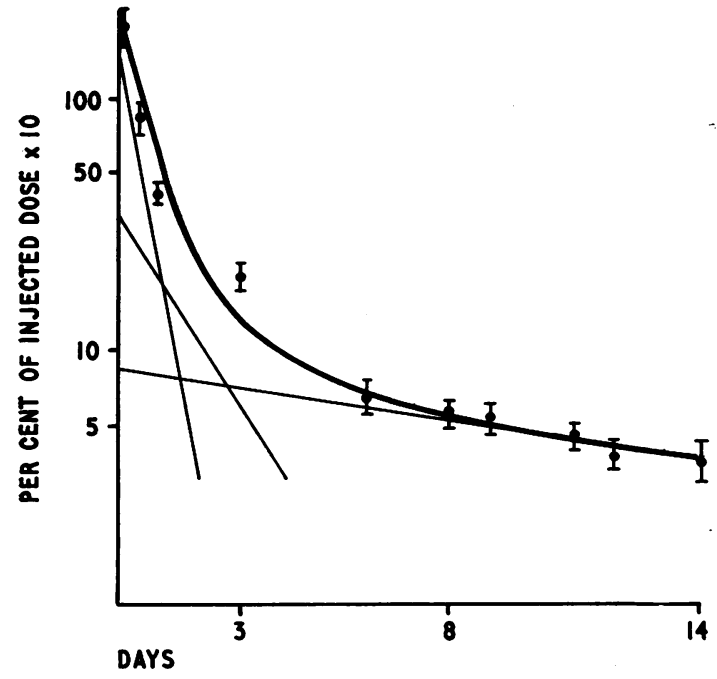

Fig. 1.-Blood: $\quad P=16 \cdot 0 \mathrm{e}^{-0.087} \mathrm{t}+3 \cdot 3 \mathrm{e}^{-0.023} \mathrm{t}+0.86 \mathrm{e}^{-0.0024 t}$

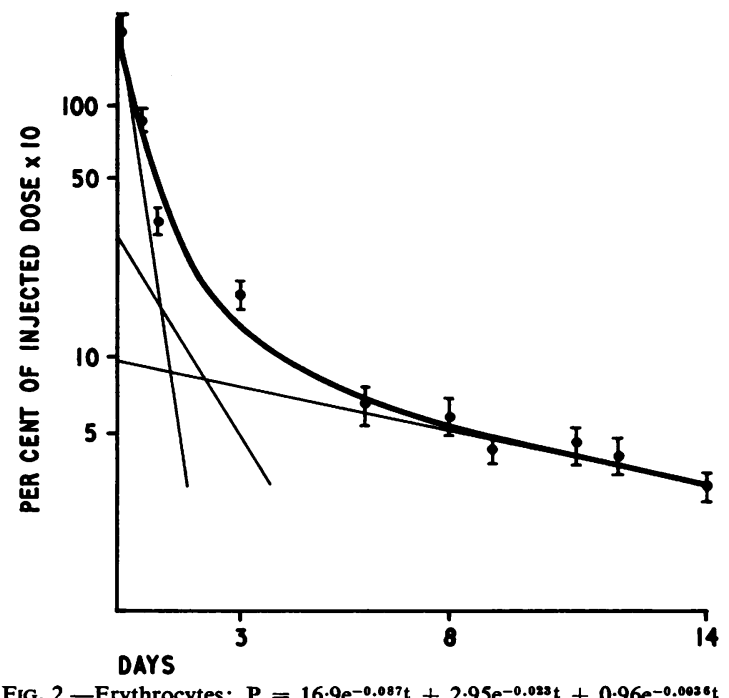

FiG. 2.-Erythrocytes: $P=16.9 e^{-0.087} t+2.95 e^{-0.023} t+0.96 e^{-0.0036 t}$

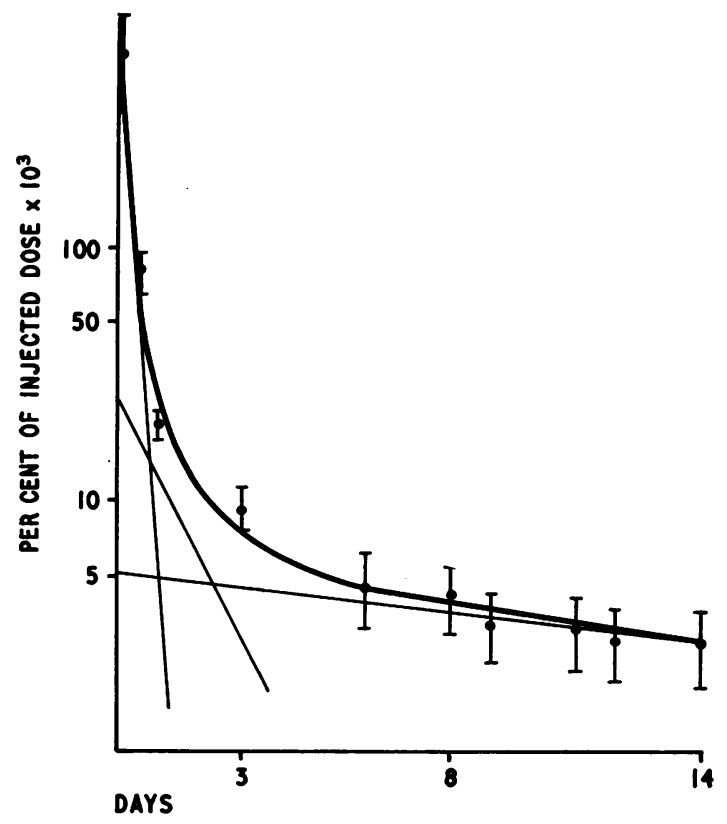

Fig. 3.-Plasma: $\quad P=0.64 e^{-0.231} t+0.024 e^{-0.031} t+0.0052 e^{-0.0021 t}$

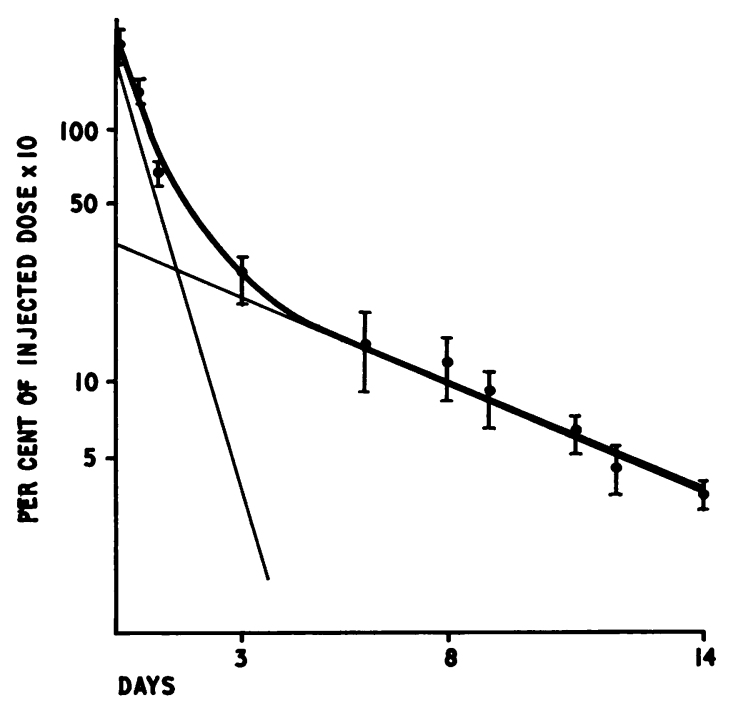

Fig. 4.-Liver: $\quad P=17 \cdot 6 \mathrm{e}^{-0.048} \mathrm{t}+3 \cdot 4 \mathrm{e}^{-0.0073 \mathrm{t}}$

FIGs. 1 to 4.-Variation with time in total ${ }^{210} \mathrm{~Pb}$ in blood and liver. 


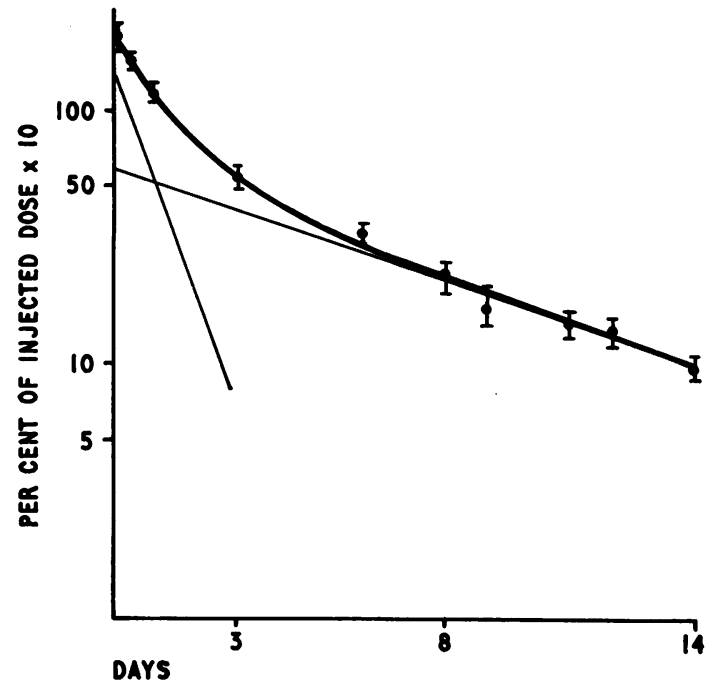

Fig. 5.-Kidney: $P=14 \cdot 1 \mathrm{e}^{-0.036 \mathrm{t}}+5.9 \mathrm{e}^{-0.0038 \mathrm{t}}$

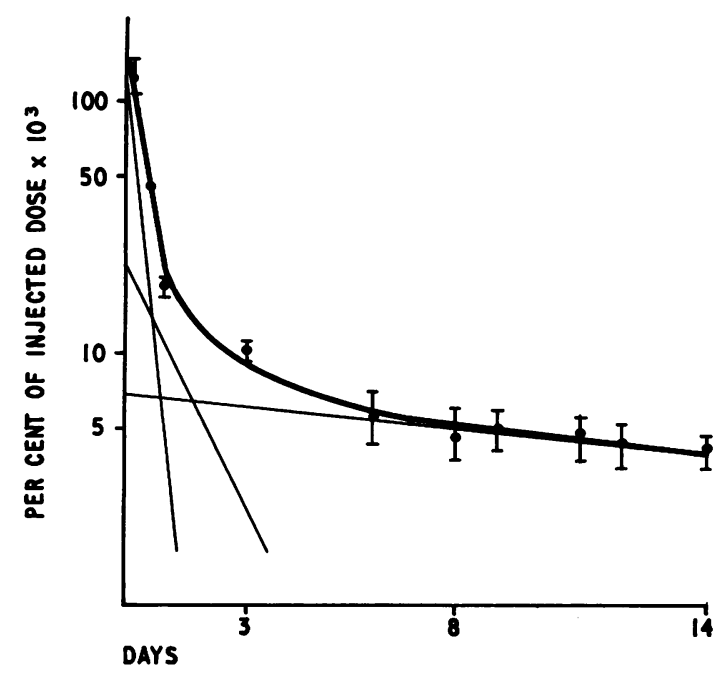

FiG. 7.-Heart: $P=0.117 \mathrm{e}^{-0.138} \mathrm{t}+0.023 \mathrm{e}^{-0.029 t}+0.008 \mathrm{e}^{-0.0028 t}$

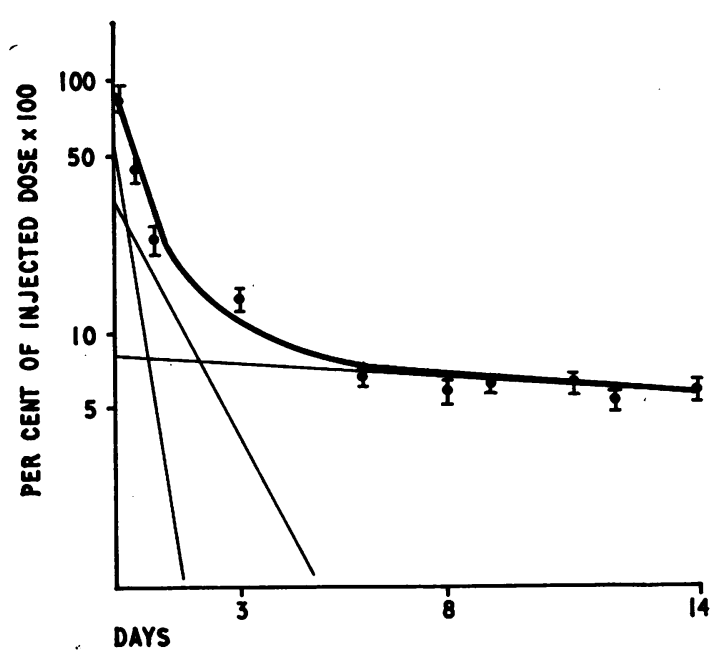

Fig. 6.-Lung: $P=0.562 e^{-0.006 t}+0.313 e^{-0.029} t+0.083 e^{-0.0011} t$

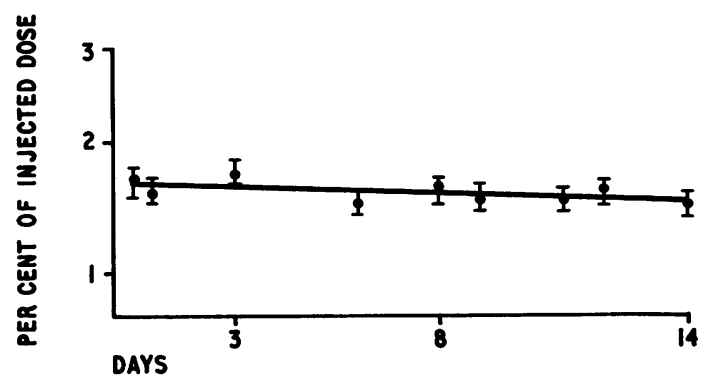

FIG. 8.-Bone: $P=1.81 \mathrm{e}^{-0.00041} \mathrm{t}$

FIGs. 5 to 8.-Variation with time $\mathrm{n}$ total ${ }^{210} \mathrm{~Pb}$ in various tissues. 
activity of $50 \mathrm{mC} / \mathrm{mM}$. For injection this was diluted with $0.0001 \mathrm{~N}$ acetic acid in $0.9 \% \mathrm{NaCl}$ in water. Activity determinations were carried out employing a well type crystal scintillation counter (Nuclear, Chicago) by estimating the $\gamma$-emission of ${ }^{210} \mathrm{~Pb}$. This is a weak radiation (0.047 m.e.v.), and efficiencies were about $2 \%$. By using a radiation analyser interference from the accompanying $\beta$ emission was reduced. In each experiment all count rates were referred to a standard prepared from the batch of ${ }^{210} \mathrm{~Pb}$ acetate used.

Treatment of Rats.-Injections were intravenous into the femoral vein under ether anaesthesia. In the main series of experiments each rat was given $0.2 \mathrm{ml}$. of lead acetate solution, $p \mathrm{H} \mathrm{4} \cdot 7$, containing $100 \mu \mathrm{g}$. of lead and enough ${ }^{210} \mathrm{~Pb}$ to record about $10^{6}$ counts $/ \mathrm{min}$. (0.94 to $\left.1 \cdot 1 \times 10^{6}\right)$. Groups of five rats were killed at intervals up to 14 days after injection. Two groups of three rats were given only $0.7 \mu \mathrm{g}$. of lead each, in $0.2 \mathrm{ml}$. of lead acetate solution, $p \mathrm{H} 5 \cdot 6$, recording about 7,000 counts/ min. These rats were killed after one and 24 hours. During the experiments the rats were kept in individual metabolism cages for separate urine and faeces collection.

Analytical Methods.-Blood was taken by heart puncture with a heparinized syringe. A portion of it was centrifuged and separated into plasmatic and cellular components. The volumes of blood, plasma, and erythrocytes were calculated from the haematocrit values by the formulae:

$$
V_{E}=0.361 W^{0.727} \text {, and } V_{P}=0.225 W^{0.707}
$$

in which $V_{E}$ and $V_{P}$ indicate the volumes of blood and plasma in millilitres and $\mathrm{W}$ the animal's weight (Poumeau-Delille, 1953).

The following tissues were obtained at necropsy: striated muscle (adducer and extensor of the thigh), liver, kidneys, lungs, spleen, heart, femur, and scapula. The remaining parts of the animal (referred to as the carcass), skeleton, tendons, muscles, muscular fascine, fur, nervous tissue, etc., were hydrolysed in hot $\mathrm{NaOH}$ $(33 \%)$. The whole gastrointestinal tract (from the stomach to the anal orifice) with its contents was hydrolysed separately in the same way. The faeces and urine were collected and the faeces were dried in a stove for 24 hours at $100^{\circ} \mathrm{C}$. and then pulverized. For counting, aliquots of the $\mathrm{NaOH}$ solution or urine were taken. Of the remaining tissues and the faeces powder the specimens themselves were counted, taking the same amount each time to minimize variations due to differences in geometry in the counting set-up.

Kinetic Analysis.-The variation of concentration with time in tissues was usually complex (Figs. 1 to 7 ) but could be satisfactorily reproduced by equations consisting of the sum of exponential terms, i.e., conc. $=\Sigma \mathrm{Ae}^{-\alpha \mathrm{t}}$, where the constants, As and $\alpha s$, were calculated from the results by the standard 'curve-stripping' method (see, e.g., Sheppard, 1962). The straight lines in these figures represent the contributions made by each exponential term. (On the logarithmic scale used here exponentials appear as straight lines.)

\section{Results}

Distribution of ${ }^{210} \mathrm{~Pb}$. - Table 1 shows the amounts of metal fixed and excreted expressed as percentages of the injected dose at various times after the injections. Each result is the mean of analyses on five rats. Recoveries ranged from 96.4 to $106.1 \%$.

TABLE 1

FIXATION AND EXCRETION OF ${ }^{210} \mathrm{~Pb}\left(10^{6}\right.$ c.p.m. $)$ AFTER AN INJECTION OF $100 \mu \mathrm{g}$. OF LEAD

\begin{tabular}{c|c|c|c}
\hline \multirow{2}{*}{$\begin{array}{c}\text { Time } \\
\text { (hours) }\end{array}$} & \multicolumn{3}{|c}{ Percentage of ${ }^{210} \mathrm{~Pb}$} \\
\cline { 2 - 3 } & In Rats & Excreted & Recovery \\
\hline 1 & $96 \cdot 8$ & $0 \cdot 28$ & $97 \cdot 1$ \\
12 & $91 \cdot 1$ & $9 \cdot 7$ & $100 \cdot 8$ \\
24 & $78 \cdot 2$ & $22 \cdot 1$ & $100 \cdot 3$ \\
72 & $67 \cdot 1$ & $36 \cdot 8$ & $104 \cdot 0$ \\
144 & $60 \cdot 8$ & $45 \cdot 3$ & $106 \cdot 1$ \\
192 & $53 \cdot 3$ & $47 \cdot 8$ & $101 \cdot 1$ \\
216 & $50 \cdot 4$ & $48 \cdot 5$ & $98 \cdot 9$ \\
264 & $51 \cdot 0$ & $49 \cdot 0$ & $100 \cdot 0$ \\
288 & $49 \cdot 8$ & $50 \cdot 4$ & $100 \cdot 2$ \\
336 & 44.8 & $51 \cdot 6$ & $96 \cdot 4$ \\
\hline
\end{tabular}

Table 2 gives the ${ }^{210} \mathrm{~Pb}$ concentrations in fresh tissues and their variation with time. Standard deviations were usually only about $10 \%$ of the means. The highest concentrations were found in the renal tissues, and, in decreasing order, in the hepatic, bone, lung, splenic and striated muscular tissues. In bone, the concentration found did not appear to depend on the kind or segment considered. There was, for example, no difference $(P>0 \cdot 2)$ between the concentrations in the femur and in the scapula.

The total ${ }^{210} \mathrm{~Pb}$ contents of whole organs were calculated and are shown in Figures 1 to 8 . By one hour after administration the metal was mainly concentrated in the blood $(20.7 \%)$, liver $(20.2 \%)$, and kidneys $(19.0 \%)$, with much lower percentages elsewhere. Of the haematic lead, $96 \%$ was bound to the cells and only $4 \%$ was found in the plasma throughout the 14 days of observation.

The curves for disappearance of ${ }^{210} \mathrm{~Pb}$ from the biological material examined could be expressed by sums of exponential functions (Figs. 1 to 7), mostly with two or three terms. The biological half-lives of the successive stages were 3 to 8 hours (phase I), 22 to 30 hours (phase II), and 192 to 610 hours (phase III). In the bone tissue, however, the ${ }^{210} \mathrm{~Pb}$ disappeared at a slow and constant rate. The curve consisted of one exponential only, and the biological half-life was 70 days (Fig. 8).

In order to find out whether the removal of ${ }^{210} \mathrm{~Pb}$ from the tissues depends on the dose given, two groups of rats were injected with a very low dose of 
TABLE 2

${ }^{210} \mathrm{~Pb}$ PER g. OF FRESH TISSUE AS PERCENTAGE OF THE INJECTED DOSE (ABOUT $100 \mu \mathrm{g}$ )

\begin{tabular}{|c|c|c|c|c|c|c|c|c|c|c|}
\hline $\begin{array}{c}\text { Time } \\
\text { (hours) }\end{array}$ & $\begin{array}{l}\text { Whole } \\
\text { Blood }\end{array}$ & $\underset{\text { Cells }}{\text { Haematic }}$ & $\underset{\left(\times 10^{2}\right)}{\text { Plasma }}$ & Liver & Kidneys & $\begin{array}{c}\text { Striated Muscle } \\
\left(\times \mathbf{1 0}^{2}\right)\end{array}$ & Femur & Lung & Spleen & $\begin{array}{c}\text { Heart } \\
\left(\times 10^{2}\right)\end{array}$ \\
\hline $\begin{array}{l}1 \text { Mean } \\
\text { S.D. }\end{array}$ & $\begin{array}{l}1 \cdot 23 \\
0 \cdot 17\end{array}$ & $\begin{array}{l}2 \cdot 65 \\
0 \cdot 36\end{array}$ & $\begin{array}{l}6 \cdot 32 \\
2 \cdot 70\end{array}$ & $\begin{array}{l}2 \cdot 51 \\
0 \cdot 32\end{array}$ & $\begin{array}{c}12 \cdot 2 \\
1 \cdot 14\end{array}$ & $\begin{array}{l}3 \cdot 50 \\
0520\end{array}$ & $\begin{array}{l}1 \cdot 52 \\
0 \cdot 140\end{array}$ & $\begin{array}{l}0.726 \\
0.061\end{array}$ & $\begin{array}{l}0.660 \\
0.044\end{array}$ & $\begin{array}{c}19 \cdot 20 \\
2 \cdot 500\end{array}$ \\
\hline $\begin{array}{l}12 \text { Mean } \\
\text { S.D. }\end{array}$ & $\begin{array}{l}0.561 \\
0.046\end{array}$ & $\begin{array}{l}1 \cdot 28 \\
0 \cdot 130\end{array}$ & $\begin{array}{l}0.960 \\
0 \cdot 180\end{array}$ & $\begin{array}{l}1 \cdot 76 \\
0 \cdot 130\end{array}$ & $\begin{array}{c}10 \cdot 8 \\
0.35\end{array}$ & $\begin{array}{l}2 \cdot 50 \\
0 \cdot 22\end{array}$ & $\begin{array}{l}2.63 \\
0.091\end{array}$ & $\begin{array}{l}0 \cdot 370 \\
0 \cdot 025\end{array}$ & $\begin{array}{l}0.590 \\
0.080\end{array}$ & $\begin{array}{l}7 \cdot 34 \\
0 \cdot 260\end{array}$ \\
\hline $\begin{array}{l}24 \text { Mean } \\
\text { S.D. }\end{array}$ & $\begin{array}{l}0.220 \\
0 \cdot 010\end{array}$ & $\begin{array}{l}0489 \\
0.029\end{array}$ & $\begin{array}{l}0230 \\
0.025\end{array}$ & $\begin{array}{l}0.759 \\
0.056\end{array}$ & $\begin{array}{l}7 \cdot 41 \\
0 \cdot 400\end{array}$ & $\begin{array}{l}1 \cdot 40 \\
0 \cdot 120\end{array}$ & $\begin{array}{l}2 \cdot 48 \\
0 \cdot 110\end{array}$ & $\begin{array}{l}0 \cdot 211 \\
0.009\end{array}$ & $\begin{array}{l}0 \cdot 510 \\
0 \cdot 100\end{array}$ & $\begin{array}{l}3 \cdot 30 \\
0 \cdot 200\end{array}$ \\
\hline $\begin{array}{l}72 \text { Mean } \\
\text { S.D. }\end{array}$ & $\begin{array}{l}0 \cdot 108 \\
0 \cdot 011\end{array}$ & $\begin{array}{l}0.226 \\
0.024\end{array}$ & $\begin{array}{l}0.099 \\
0.020\end{array}$ & $\begin{array}{l}0 \cdot 380 \\
0 \cdot 072\end{array}$ & $\begin{array}{l}3 \cdot 02 \\
0 \cdot 230\end{array}$ & $\begin{array}{l}0.480 \\
0.041\end{array}$ & $\begin{array}{l}2 \cdot 75 \\
0 \cdot 130\end{array}$ & $\begin{array}{l}0 \cdot 103 \\
0.007\end{array}$ & $\begin{array}{l}0.210 \\
0.024\end{array}$ & $\begin{array}{l}1.60 \\
0.065\end{array}$ \\
\hline $\begin{array}{l}144 \text { Mean } \\
\text { S.D. }\end{array}$ & $\begin{array}{l}0.034 \\
0.004\end{array}$ & $\begin{array}{l}0.070 \\
0.012\end{array}$ & $\begin{array}{l}0.043 \\
0.013\end{array}$ & $\begin{array}{l}0.168 \\
0.044\end{array}$ & $\begin{array}{l}1 \cdot 78 \\
0 \cdot 248\end{array}$ & $\begin{array}{l}0.250 \\
0.055\end{array}$ & $\begin{array}{l}2 \cdot 30 \\
0 \cdot 132\end{array}$ & $\begin{array}{l}0.065 \\
0.004\end{array}$ & $\begin{array}{l}0.241 \\
0.064\end{array}$ & $\begin{array}{l}0.980 \\
0 \cdot 230\end{array}$ \\
\hline $\begin{array}{l}192 \text { Mean } \\
\text { S.D }\end{array}$ & $\begin{array}{l}0.034 \\
0.003\end{array}$ & $\begin{array}{l}0 \cdot 076 \\
0.012\end{array}$ & $\begin{array}{l}0.045 \\
0.012\end{array}$ & $\begin{array}{l}0 \cdot 142 \\
0.037\end{array}$ & $\begin{array}{l}1 \cdot 35 \\
0 \cdot 172\end{array}$ & $\begin{array}{l}0 \cdot 160 \\
0.040\end{array}$ & $\begin{array}{l}2 \cdot 49 \\
0 \cdot 128\end{array}$ & $\begin{array}{l}0.046 \\
0.003\end{array}$ & $\begin{array}{l}0.165 \\
0.045\end{array}$ & $\begin{array}{l}0 \cdot 842 \\
0 \cdot 208\end{array}$ \\
\hline $\begin{array}{l}216 \text { Mean } \\
\text { S.D. }\end{array}$ & $\begin{array}{l}0.033 \\
0.004\end{array}$ & $\begin{array}{l}0.055 \\
0.006\end{array}$ & $\begin{array}{l}0.036 \\
0.011\end{array}$ & $\begin{array}{l}0 \cdot 112 \\
0.028\end{array}$ & $\begin{array}{l}1 \cdot 09 \\
0 \cdot 153\end{array}$ & $\begin{array}{l}0 \cdot 140 \\
0.038\end{array}$ & $\begin{array}{l}2 \cdot 44 \\
0.114\end{array}$ & $\begin{array}{l}0.054 \\
0.003\end{array}$ & $\begin{array}{l}0.183 \\
0.032\end{array}$ & $\begin{array}{l}0.816 \\
0.142\end{array}$ \\
\hline $\begin{array}{l}264 \text { Mean } \\
\text { S.D. }\end{array}$ & $\begin{array}{l}0.026 \\
0.002\end{array}$ & $\begin{array}{l}0.050 \\
0.006\end{array}$ & $\begin{array}{l}0.028 \\
0.011\end{array}$ & $\begin{array}{l}0.073 \\
0.010\end{array}$ & $\begin{array}{l}0.917 \\
0.093\end{array}$ & $\begin{array}{l}0 \cdot 103 \\
0.014\end{array}$ & $\begin{array}{l}2 \cdot 33 \\
0 \cdot 100\end{array}$ & $\begin{array}{l}0.057 \\
0.003\end{array}$ & $\begin{array}{l}0 \cdot 157 \\
0.010\end{array}$ & $\begin{array}{l}0.780 \\
0.166\end{array}$ \\
\hline $\begin{array}{l}288 \text { Mean } \\
\text { S.D. }\end{array}$ & $\begin{array}{l}0.022 \\
0.002\end{array}$ & $\begin{array}{l}0.054 \\
0.008\end{array}$ & $\begin{array}{l}0.029 \\
0.009\end{array}$ & $\begin{array}{l}0.054 \\
0.009\end{array}$ & $\begin{array}{l}0.933 \\
0.133\end{array}$ & $\begin{array}{l}0.106 \\
0.012\end{array}$ & $\begin{array}{l}2 \cdot 34 \\
0 \cdot 117\end{array}$ & $\begin{array}{l}0.043 \\
0.002\end{array}$ & $\begin{array}{l}0.124 \\
0.026\end{array}$ & $\begin{array}{l}0.738 \\
0.127\end{array}$ \\
\hline $\begin{array}{l}336 \text { Mean } \\
\text { S.D. }\end{array}$ & $\begin{array}{l}0.023 \\
0.004\end{array}$ & $\begin{array}{l}0.038 \\
0.003\end{array}$ & $\begin{array}{l}0.027 \\
0.010\end{array}$ & $\begin{array}{l}0.039 \\
0.004\end{array}$ & $\begin{array}{l}0.640 \\
0.038\end{array}$ & $\begin{array}{l}0.093 \\
0.016\end{array}$ & $\begin{array}{l}2.23 \\
0.084\end{array}$ & $\begin{array}{l}0.047 \\
0.003\end{array}$ & $\begin{array}{l}0.106 \\
0.024\end{array}$ & $\begin{array}{l}0.700 \\
0.080\end{array}$ \\
\hline
\end{tabular}

TABLE 3

${ }^{210} \mathrm{~Pb}$ PER g. OF FRESH TISSUE AND TOTAL ${ }^{210} \mathrm{~Pb}$ IN URINE, FAECES, AND GASTROINTESTINAL TRACT AFTER INJECTION OF $0.7 \mu \mathrm{g} . /$ RAT

\begin{tabular}{|c|c|c|c|c|c|c|c|c|c|c|c|}
\hline $\begin{array}{c}\text { Time } \\
\text { (hours) }\end{array}$ & $\begin{array}{l}\text { Whole } \\
\text { Blood }\end{array}$ & $\underset{\text { Cells }}{\text { Haematic }}$ & Plasma & Liver & Kidneys & Lungs & Spleen & Femur & Urine & Faeces & $\begin{array}{c}\text { Gastro- } \\
\text { intestinal } \\
\text { Tract }\end{array}$ \\
\hline 1 & $\begin{array}{l}3.04 \\
2.79 \\
3.37\end{array}$ & $\begin{array}{l}6.06 \\
5.81 \\
6.35\end{array}$ & $\begin{array}{l}0.25 \\
0.13 \\
0.37\end{array}$ & $\begin{array}{l}3 \cdot 76 \\
3 \cdot 18 \\
4 \cdot 36\end{array}$ & $\begin{array}{l}13.8 \\
11.8 \\
15.9\end{array}$ & $\begin{array}{l}1.16 \\
1.05 \\
1.29\end{array}$ & $\begin{array}{l}1.46 \\
1.36 \\
1.57\end{array}$ & $\begin{array}{l}1.42 \\
1.32 \\
1.53\end{array}$ & E & E & $\begin{array}{l}4.46 \\
3.08 \\
4.87\end{array}$ \\
\hline 24 & $\begin{array}{l}0.71 \\
0.69 \\
0.73\end{array}$ & $\begin{array}{l}1.74 \\
1.70 \\
1.77\end{array}$ & E & $\begin{array}{l}1.25 \\
0.99 \\
1.52\end{array}$ & $\begin{array}{r}10 \cdot 1 \\
9.6 \\
10 \cdot 7\end{array}$ & $\begin{array}{l}0.46 \\
0.34 \\
0.59\end{array}$ & $\begin{array}{l}0.42 \\
0.31 \\
0.52\end{array}$ & $\begin{array}{l}1.57 \\
1.40 \\
1.77\end{array}$ & $\begin{array}{l}5.69 \\
5.36 \\
6.05\end{array}$ & $\begin{array}{l}14 \cdot 0 \\
12 \cdot 8 \\
15 \cdot 3\end{array}$ & $\begin{array}{l}5.46 \\
4.00 \\
7.20\end{array}$ \\
\hline
\end{tabular}

Results are given for each rat as percentages of the injected dose.

${ }^{210} \mathrm{~Pb}, 0 \cdot 7 \mu \mathrm{g}$. lead/rat, so as to alter negligibly the biological equilibrium. The rats were killed one and 24 hours after injection, none later. Later sampling would have given imprecise results owing to the low specific activity of the lead; and if dose does have an effect it is expected to be greatest in this initial period.

Table 3 shows a big decrease in the metal concentration in the different tissues, after from one to 24 hours, rather similar to that found in rats given 100 $\mu$ g., i.e., the kinetics were independent of the dose.

Excretion of ${ }^{210} \mathrm{~Pb}$. - Lead was excreted in both the faeces and urine. One hour after injection the urine of two rats contained 0.27 and $0.29 \%$ of the dose respectively. In this time no lead was found in the faeces, but that found in the gastrointestinal tract probably represented metal excreted through the bile (Fig. 9). Accordingly, at short times after injection the variation with time of the radioactivity in the tract is similar to the variation with time of the ${ }^{210} \mathrm{~Pb}$ excreted in the faeces (Fig. 9) when allowance is made for the time needed for the metal to pass through the intestines.

Concentrations in the faeces and urine reached a maximum at 12 to 24 hours, were maintained for 72 to 96 hours, and then decreased asymptotically, following the same course (Fig. 9). Over the whole 14 days the faecal excretion of ${ }^{210} \mathrm{~Pb}$ was $35.7 \%$ (fiducial limits 30.4 to $40.1 \%$ ) of the total dose, and was over twice the amount excreted in the urine $(15.9 \%$, fiducial limits 13.0 to $18.8 \%)$. The total excreted was thus $51.6 \%$ of the dose (Table 4).

After a low dose of $0.7 \mu \mathrm{g}$./rat the percentages excreted in the urine and faeces and found in the gastrointestinal tract were similar to the corresponding percentages for rats given the larger dose (Table 3). Again, the dose did not affect the kinetics. 
CUMULATIVE URINARY AND FAECAL EXCRETION OF ${ }^{210} \mathrm{~Pb}$ AS PERCENTAGE OF THE INJECTED DOSE (ABOUT $100 \mu \mathrm{g}$.)

\begin{tabular}{|c|c|c|c|c|c|c|c|c|c|c|c|}
\hline & & \multicolumn{10}{|c|}{ Time (hours) } \\
\hline & & 12 & 24 & 48 & 72 & 96 & 144 & 192 & 216 & 288 & 336 \\
\hline Urine & $\begin{array}{l}\text { Mean } \\
\text { S.D. }\end{array}$ & $\begin{array}{l}2.28 \\
0.32\end{array}$ & $\begin{array}{l}5.78 \\
0.36\end{array}$ & $8 \cdot 84$ & 11.08 & $\begin{array}{c}12.21 \\
0.78\end{array}$ & 13.67 & $\begin{array}{r}14.30 \\
1.29\end{array}$ & 14.59 & $15 \cdot 40$ & $\begin{array}{r}15.90 \\
1.12\end{array}$ \\
\hline Faeces & $\begin{array}{l}\text { Mean } \\
\text { S.D. }\end{array}$ & $\begin{array}{l}7 \cdot 36 \\
1.45\end{array}$ & $\begin{array}{r}16.25 \\
1.33\end{array}$ & 22.99 & 25.92 & $\begin{array}{r}28.94 \\
1.66\end{array}$ & 31.66 & $\begin{array}{r}33.52 \\
2.06\end{array}$ & 33.89 & 35.02 & $\begin{array}{r}35.74 \\
2.08\end{array}$ \\
\hline
\end{tabular}

\section{Discussion}

In the blood, $96 \%$ of the lead was bound to the cellular elements and $4 \%$ was in the plasma. The ratio was constant during the whole period of observation. These results agree with those obtained by Mortensen and Kellogg (1944) in the dog and by Schubert and White (1952) in the rat.

The study by Mortensen and Kellogg of the haematic distribution of ${ }^{210} \mathrm{~Pb}$ in relation to the injected dose $(0.1$ to $100 \mathrm{mg}$. per animal) and to the time elapsed since the injection (from 15 minutes to 192 hours) showed that, with doses not higher than $5 \mathrm{mg}$. per dog, $98 \%$ of the haematic metal was present in the cellular fraction, and throughout the experimental period. With higher doses (30 to $100 \mathrm{mg}$. per dog) $40 \%$ was initially bound to the cells, but after 24 hours $98 \%$ was bound, indicating a more rapid decrease of the concentration in the plasma. Thus metal passes from the plasma to the cells of the blood and of the other tissues. Our results are in agreement with the findings of Schubert and White (1952). These authors observed that in the rat 25 minutes after the intravenous injection of 0.2 to $0.6 \mathrm{mg}$. of carrier-free ${ }^{210} \mathrm{~Pb}, 10 \%$ of metal was present in the blood, mainly in the cellular fraction, whereas with a dose of $1.03 \mathrm{mg}$. of lead, $6 \%$ of the dose was bound to the haematic cells and $22 \%$ was present in the plasma. Thus. lead is bound in the blood mainly to the cells and is only found in appreciable quantities in the plasma after very high doses.

Table 2 shows that in the rat lead has a wide distribution. A few hours after injection the metal 
almost disappeared from the plasma, but more remained in other tissues. The highest concentrations were found in the renal tissue and in a decreasing order in the hepatic, pulmonary, splenic, cardiac, and striated muscular tissues. These data agree with the previous observations of Schubert and White (1952), Calhoun et al. (1954), and Miani and Viterbo (1958).

The kinetic analysis shows three types of curve for the disappearance of lead from the tissues and organs.

From bone removal is slow and can be represented by a single exponential function over the limited time range studied. The 14-day period of observation is too short in comparison with the biological half-life of 70 days for any detailed conclusions to be drawn. The slow removal may result either from very firm binding of lead to the bone constituents or from the slow metabolism of bone. The skeleton constitutes about $10 \%$ of the body weight. The present results indicate that $\mathbf{4 0}$ to $50 \%$ is held in the skeleton and is only removed very slowly.

In liver and kidney, the disappearance curves can be represented as the sum of two exponentials, and in the other tissues by the sum of three exponentials. The latter type of curve could be explained by a model such as that in Figure 10. The ionic lead injected can be supposed to enter the extracellular space very shortly after injection. It is then lost from this partly to blood and partly to the intracellular space. Inside the cells the ionic lead may then be bound by

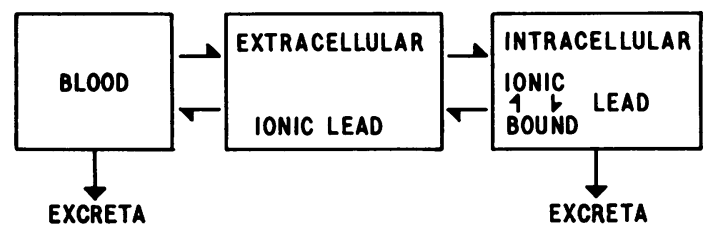

Fig. 10.-The movement of ${ }^{310} \mathrm{~Pb}$ in the rat. absorption or complexing, or may return to the extracellular space and thence to the blood. The bound lead may either be released as ionic lead inside the cell, i.e., there may be an intracellular equilibrium, or it may be eliminated from the cells as complexed lead. Such a system is expected to fit a curve which is the sum of three exponentials, and explains why in the liver and kidney only two exponentials are required. In these organs the extracellular lead would be mainly in bile and urine and therefore removed too rapidly from the system to contribute. If the lead is directly removed from the intracellular compartment through the excreta, the curve should be the sum of two exponentials. Such a picture is probably too simple in detail; but the existence of different phases of excretion indicates the preserce of a complex lead metabolism. The initial rapid phases show the removal of the metal present as ion in the intercellular and intracellular spaces, possibly weakly bound, while the slow final phase represents the removal of the metal fixed in the cells, perhaps as an organic complex.

\section{REFERENCES}

Aub, J. C., Fairhall, L. T., Minot, A. S., and Reznikoff, P. (1925). Medicine (Baltimore), 4, 1 .

Calhoun, J. A., McLean, R., Hudson, J. C., and Aub, J. C. (1954). Arch. industr. Hyg., 9, 9.

Dinischiotu, G. T., Nestorescu, B., Radulescu, I. C., Ionescu, C. Preda, N., and Ilutza, G. (1960). Brit. J. industr. Med., 17, 141. Jowett, M. (1932). Biochem. J., 26, 2108.

Maxwell, L. C., and Bischoff, F. (1929). J. Pharmacol. exp. Ther., 37,413 .

Miani, N., and Viterbo, B. (1958).Z.Zellforsch., 49, 188.

Mortensen, R. A., and Kellogg, K. E. (1944). J. cell. comp. Physiol., $23,11$.

Nelson, K. W., and Hamm, R. E. (1958). Arch. industr. Hlth, 17, 38.

Poumeau-Delille, G. (1953). Techniques Biologiques en Endocrinologie Expérimentale chez le Rat, p. 23. Masson, Paris.

Schubert, J., and White, M. R. (1952). J. Lab. clin. Med., 39. 260 Sheppard, C. W. (1962). Basic Principles of the Tracer Method. Wiley, New York.

Teisinger, J. (1935). Biochem. Z., 277, 178.

-, Zumanová, R., and Zezula, I. (1958). Arch. industr. Hlth, 17, 295. 